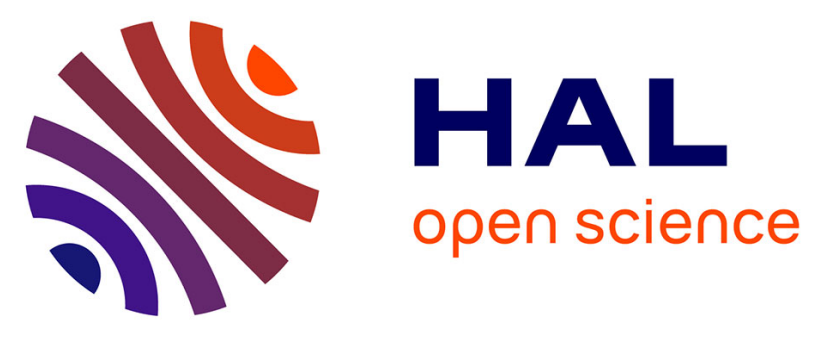

\title{
Hydrogen-bonded oligothiophene rosettes with a benzodithiophene terminal unit: self-assembly and application to bulk heterojunction solar cells
}

Hayato Ouchi, Xu Lin, Takahiro Kizaki, Deepak D. Prabhu, Fabien Silly, Takashi Kajitani, Takanori Fukushima, Ken-Ichi Nakayama, Shiki Yagai

\section{To cite this version:}

Hayato Ouchi, Xu Lin, Takahiro Kizaki, Deepak D. Prabhu, Fabien Silly, et al.. Hydrogen-bonded oligothiophene rosettes with a benzodithiophene terminal unit: self-assembly and application to bulk heterojunction solar cells. Chemical Communications, 2016, 52, pp.7874. 10.1039/C6CC03430F . cea-01485666

\section{HAL Id: cea-01485666 https://hal-cea.archives-ouvertes.fr/cea-01485666}

Submitted on 9 Mar 2017

HAL is a multi-disciplinary open access archive for the deposit and dissemination of scientific research documents, whether they are published or not. The documents may come from teaching and research institutions in France or abroad, or from public or private research centers.
L'archive ouverte pluridisciplinaire HAL, est destinée au dépôt et à la diffusion de documents scientifiques de niveau recherche, publiés ou non, émanant des établissements d'enseignement et de recherche français ou étrangers, des laboratoires publics ou privés. 
CrossMark < click for updates

Cite this: Chem. Commun., 2016, 52,7874

Received 24th April 2016 Accepted 21st May 2016

DOI: $10.1039 / c 6 c c 03430 f$

www.rsc.org/chemcomm

\section{Hydrogen-bonded oligothiophene rosettes with a benzodithiophene terminal unit: self-assembly and application to bulk heterojunction solar cells $\dagger$}

\author{
Hayato Ouchi, ${ }^{a}$ Xu Lin, ${ }^{* a}$ Takahiro Kizaki, ${ }^{b}$ Deepak D. Prabhu, ${ }^{a}$ Fabien Silly, ${ }^{c}$ \\ Takashi Kajitani, ${ }^{\text {de }}$ Takanori Fukushima, ${ }^{d}$ Ken-ichi Nakayama ${ }^{\text {bf }}$ and Shiki Yagai*af
}

\begin{abstract}
Benzodithiophene-functionalized oligothiophene with barbituric acid hydrogen-bonding unit self-assembles into nanoscopic structures via the formation of rosettes. The nanostructures show a power conversion efficiency of $3 \%$ upon mixing with $\mathrm{PC}_{61} \mathrm{BM}$ in bulkheterojunction solar cells without thermal annealing.
\end{abstract}

Bulk heterojunction (BHJ) small molecular organic photovoltaic (OPV) devices, despite their inferior performance compared to the polymer or inorganic hybrid counterparts, still attract much attention owing to their outstanding cost-effectiveness and large-area applicability through solution processing in addition to diversity in available organic semiconductors. ${ }^{1,2}$ For BHJOPV devices, control over the self-assembly of semiconducting materials through solvent processing is of primary importance in view of creating ideal $\mathrm{p}-\mathrm{n}$ heterojunction nanostructures. ${ }^{3}$ Thus, enormous supramolecular insight into how molecular aggregation can be controlled in solution as well as in the bulk state, provided by a myriad of research examples, must contribute largely to this advanced research field. ${ }^{4}$ However, multiple hydrogenbonding interactions, a typical supramolecular tool to control molecular assembly, have been rarely applied for organic photovoltaic materials, due to the requirements of installing solubilizing yet non-conducting long alkyl chains into molecular scaffolds. ${ }^{5}$

\footnotetext{
${ }^{a}$ Department of Applied Chemistry and Biotechnology, Graduate School of Engineering, Chiba University, 1-33 Yayoi-cho, Inage-ku, Chiba 263-8522, Japan. E-mail: yagai@faculty.chiba-u.jp; Fax: +81-(0)43-290-3039; Tel: $+81-(0) 43-290-3368$

${ }^{b}$ Department of Organic Device Engineering, Graduate School of Science and Engineering, Yamagata University, 4-3-16 Jonan, Yonezawa, Yamagata 992-8510, Japan

${ }^{c}$ TITANS, SPEC, CEA, CNRS, Université Paris-Saclay, CEA Saclay, F-91191 Gif sur Yvette, France

${ }^{d}$ Chemical Resources Laboratory, Tokyo Institute of Technology, 4259 Nagatsuta, Midori-ku, Yokohama 226-8503, Japan

${ }^{e}$ RIKEN SPring-8 Center, 1-1-1 Kouto, Sayo, Hyogo 679-5148, Japan

${ }^{f}$ CREST-JST, Chiyoda-ku, Tokyo 102-0075, Japan

$\dagger$ Electronic supplementary information (ESI) available: Detailed synthesis and characterization of 1-BDT; the absorption spectra and transfer OFET characteristics of 1 and 1-BDT. See DOI: 10.1039/c6cc03430f
}

As a promising supramolecular design for hydrogen-bonding semiconductors applicable to the organic photovoltaic application, we have recently developed barbituric acid-functionalized oligothiophenes, wherein solubilizing short alkyl chains are grafted onto the $\pi$-conjugated backbone. ${ }^{6}$ For example, compound $\mathbf{1}$ is organized into semiconducting nanorods through the formation of hexameric hydrogen-bonded aggregates (rosettes) via solution processing (Fig. 1). This self-assembly pathway occurred in the presence of $\mathrm{PC}_{61} \mathrm{BM}\left([6,6]\right.$-phenyl- $\mathrm{C}_{61}$-butyric acid methyl ester), and the resulting $\mathrm{p}-\mathrm{n}$ blend film showed a power conversion efficiency (PCE) of $2.1 \%$ in the BHJ-OPV device under optimized conditions. To further improve the functionality of this supramolecular design, herein we have devised a strategy to endfunctionalization of 1 with the semiconducting backbone (Fig. 1).

An alkoxy substituted benzo[1,2-b:4,5- $\left.b^{\prime}\right]$ dithiophene (BDT) unit is a promising electron donating building block for organic photovoltaics due to its excellent charge carrier transporting properties arising from a large and planar $\pi$-conjugated structure. $^{7}$ We expect that a low charge carrier mobility $\left(\sim 10^{-7} \mathrm{~cm}^{2} \mathrm{~V}^{-1} \mathrm{~s}^{-1}\right.$, vide infra $)$ of our parent compound 1 can be improved by its end-functionalization with the BDT unit. We thus synthesized 1-BDT according to Scheme S1 (ESI $\dagger$ ). In the previous study, we confirmed the formation of a hexameric rosette for $\mathbf{1}$ by means of scanning tunneling microscopy (STM) at the liquid-solid interface. To understand the impact of the BDT unit on this self-assembling motif, we performed the STM analysis of 1-BDT.

Fig. 2a shows that 1-BDT forms a sophisticated self-assembled structure at the interface between 1-phenyloctane and highly oriented pyrolytic graphite (HOPG). The molecules preferentially

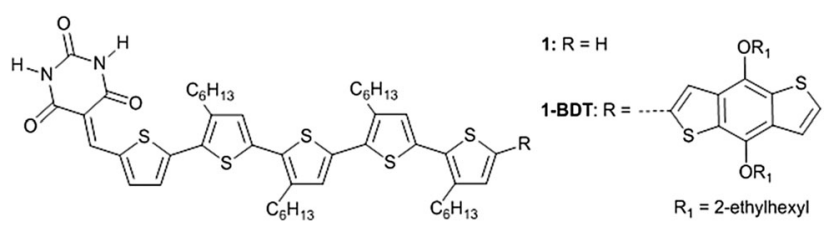

Fig. 1 Molecular structures of 1 and 1-BDT. 

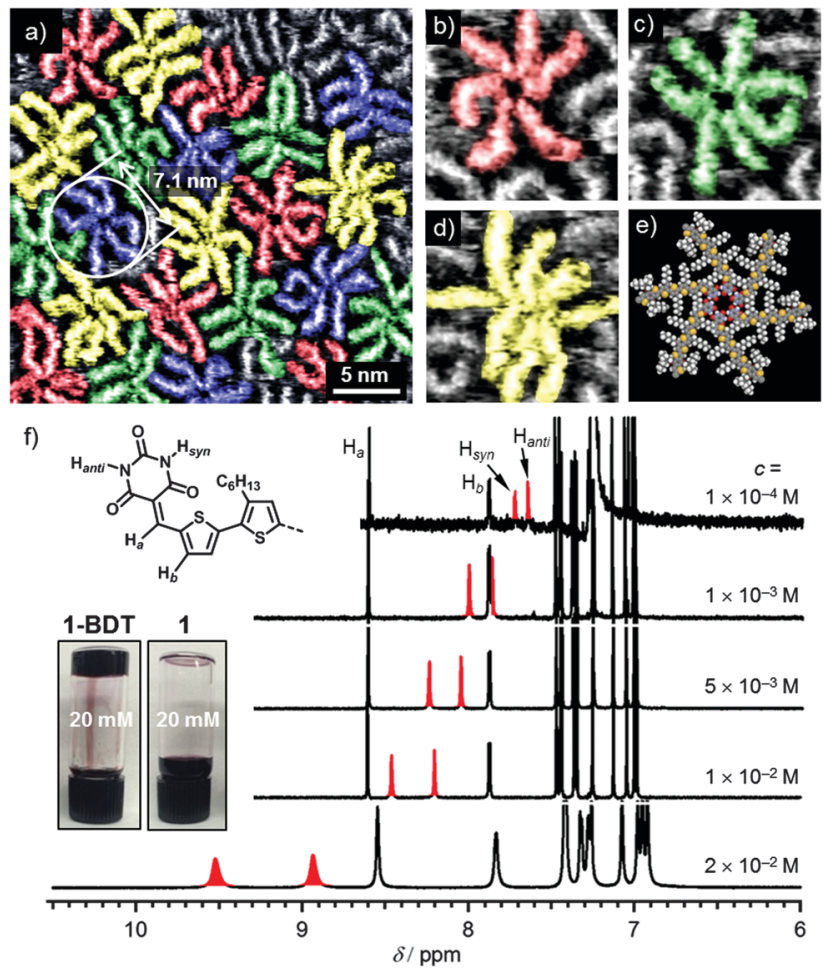

Fig. 2 (a) STM image of 1-BDT at the 1-phenyloctane-HOPG interface $\left(I_{\mathrm{t}}=9 \mathrm{pA}, V_{\mathrm{s}}\right)=-0.55 \mathrm{~V}$. Concentration of solution is $5.0 \times 10^{-6} \mathrm{M}$. (b) $-(\mathrm{d})$ Rosettes composed of (b) 6, (c) 7, and (d) 8 molecules, respectively. Image size: $9 \times 9 \mathrm{~nm}^{2}$. (e) Molecular modelled 6-membered rosette of 1-BDT (f) Concentration-dependent ${ }^{1} \mathrm{H}$ NMR spectra of 1-BDT ( $c=1 \times 10^{-4}-2 \times$ $\left.10^{-2} \mathrm{M}\right)$ in $\mathrm{CDCl}_{3}$. Inset: $\mathrm{CHCl}_{3}$ gel of 1-BDT and $\mathrm{CHCl}_{3}$ solution of 1 obtained after $0.5 \mathrm{~h}$ upon cooling homogeneous hot solutions $(C=2 \times$ $\left.10^{-2} \mathrm{M}\right)$ to room temperature.

form closely packed rosette structures on the surface. The different rosettes have been colored in green, red, blue and yellow as a guide to the eye. Isolated molecules are shown in grey. The majority of rosettes are composed of 6 molecules (Fig. 2b), but rosettes composed of 7 and 8 molecules were also observed (Fig. 2c and d). The arms of the rosette can adopt different conformations on the surface, due to the flexibility of the oligothiophene backbone. ${ }^{8}$ Despite the variation in conformation and the number of molecules, the average diameter of rosettes is uniform and is $\sim 7 \mathrm{~nm}$, similar to the diameter of the molecular modeled rosette structure composed of 6 molecules (7.1 nm, Fig. 2e).

The formation of hydrogen-bonded rosettes using 1-BDT was supported by the ${ }^{1} \mathrm{H}$ NMR study in $\mathrm{CDCl}_{3}$. Fig. 2f shows the concentration-dependent ${ }^{1} \mathrm{H}$ NMR spectra of 1-BDT. At $1 \times 10^{-4} \mathrm{M}$, sharp signals of $\mathrm{NH}$ protons of the barbituric acid moiety $\left(\mathrm{H}_{\text {syn }}\right.$ and $\left.\mathrm{H}_{\text {anti }}\right)$ appeared at 7.73 and $7.65 \mathrm{ppm}$, respectively. ${ }^{6}$ Upon increasing the concentration, the $\mathrm{NH}$ signals showed gradual downfield shifts, indicating hydrogen bonding. The difference in the chemical shift value between the two proton signals increased from $\Delta \delta=0.13 \mathrm{ppm}$ at $c=1 \times 10^{-4} \mathrm{M}$ to $\Delta \delta=0.58 \mathrm{ppm}$ at $c=2 \times 10^{-2} \mathrm{M}$, which indicates that these protons experience distinct deshielding effects from the neighboring molecules. The finding may indicate the formation of a screw-shaped hydrogen-bonded rosette motif, as shown in Fig. $2 \mathrm{~b}$. The signals of the olefinic proton $\left(\mathrm{H}_{a}\right)$ and the thiophene proton $\left(\mathrm{H}_{b}\right)$ did not show such a large change upon increasing the concentration to $1 \times 10^{-2} \mathrm{M}$. These spectral changes are similar to those of the previously reported molecule $\mathbf{1}$, and suggest that 1-BDT forms well-defined hydrogen bonded oligomers, rather than polymeric assemblies arising from a competing tape-like hydrogen-bonding motif in $\mathrm{CDCl}_{3}$. Interestingly, the solution at $c=2 \times 10^{-2} \mathrm{M}$ turned into a gel upon standing for $30 \mathrm{~min}$ at room temperature (inset in Fig. 2f). The gelation in $\mathrm{CDCl}_{3}$ was not observed for $\mathbf{1}$, suggesting that the BDT units decrease the solubility appreciably.

Since the formation of gel in $\mathrm{CDCl}_{3}$ implies that 1-BDT organizes into higher-order nanoscopic aggregates through the formation of rosettes, the chloroform gel $\left(c=2 \times 10^{-2} \mathrm{M}\right)$ was studied by atomic force microscopy (AFM) upon spin-coating onto the HOPG substrate. However, only granular objects with $50 \mathrm{~nm}$ in size were visualized (Fig. S5, ESI ${ }^{\dagger}$ ). In order to observe individual columnar aggregates formed by stacked rosettes, a dilute solution of 1-BDT $\left(1 \times 10^{-4} \mathrm{M}\right)$ in toluene, which is less polar than $\mathrm{CHCl}_{3}$, was drop-cast onto the HOPG substrate and the solvent was allowed to evaporate slowly under ambient conditions to grow the columnar aggregates. ${ }^{6}$ The AFM images of the substrate displayed islands composed of densely aligned short nanorods with lengths of $20-80 \mathrm{~nm}$ (Fig. 3a). The crosssectional analysis of the aligned nanorods showed that the average top-to-top distance between neighbouring rods was $5.3 \mathrm{~nm}$ whereas their average height was $4.0 \mathrm{~nm}$. The discrepancy between these dimensions may indicate a tilted stacking of rosettes to form a column with an ellipsoidal cross-section.

The UV-vis absorption spectrum of a dilute $\mathrm{CHCl}_{3}$ solution $\left(c=1 \times 10^{-5} \mathrm{M}\right)$ of 1-BDT showed two absorption bands similarly to 1 (Fig. S6, ESI $\dagger$ ). However, the absorption intensity of the lower wavelength band is much higher for 1-BDT. The increased absorption intensity in the lower wavelength region is ascribable to the contribution of BDT units. ${ }^{7 c}$ Interestingly, the spectrum of the thin film prepared by spin-coating a chloroform solution exhibited a strong bathochromic and hypochromic shift for the transition of the BDT unit, suggesting strong aggregation of this unit in the solid state. The absorption band of the oligothiophene scaffold is broadened due to $\pi-\pi$
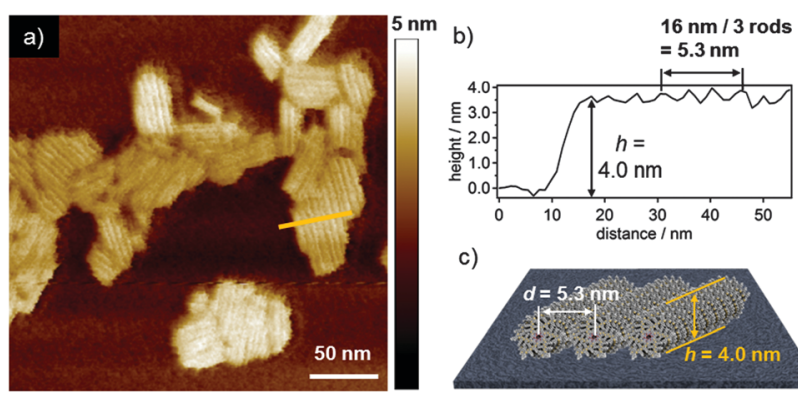

c)

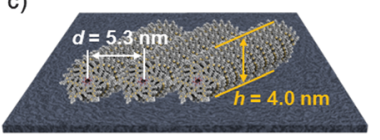

Fig. 3 (a) AFM image of thin film prepared by drop-casting toluene solution ( $c=1 \times 10^{-4} \mathrm{M}$ ) of 1-BDT onto HOPG. (b) Cross-sectional analysis along the yellow line in (a). (c) Schematic representations of aligned nanorods of 1-BDT on the substrate. 
Table 1 Optical and electronic properties of 1-BDT and 1

\begin{tabular}{llllll}
\hline Compounds & $\begin{array}{l}\lambda_{\max }^{\text {solution }} \\
(\mathrm{nm})\end{array}$ & $\lambda_{\max }^{\text {film }}(\mathrm{nm})$ & $\begin{array}{l}E_{\mathrm{g}}^{\text {film }} \\
(\mathrm{eV})\end{array}$ & $\begin{array}{l}E_{\text {HOMO }} \\
(\mathrm{eV})\end{array}$ & $\begin{array}{l}E_{\text {LUMO }} \\
(\mathrm{eV})\end{array}$ \\
\hline $\mathbf{1 - B D T}$ & 418,550 & 555 & 1.80 & -5.00 & -3.20 \\
$\mathbf{1}$ & 388,552 & $334,418,542$ & 1.84 & -5.06 & -3.22
\end{tabular}

stacking aggregation. The optical bandgap of 1-BDT in the film state, estimated from the absorption onset $\left(\lambda_{\text {onset }}=688 \mathrm{~nm}\right)$, is $E_{\mathrm{g}}=1.80 \mathrm{eV}$. The HOMO energy level of 1-BDT was evaluated using photoelectron yield spectroscopy under atmospheric pressure and was found to be $-5.00 \mathrm{eV}$, which is almost identical to that of $\mathbf{1}(-5.06 \mathrm{eV})$. The value of the LUMO energy level, thus estimated by subtracting the value of the HOMO energy level from the optical band gap, is $-3.20 \mathrm{eV}$, which is also comparable to that of $\mathbf{1}$ (Table 1 ). These results indicate that the introduction of the BDT unit has a minimal impact on the electronic structure of the $\pi$-conjugated system.

BHJ solar cells were fabricated using 1-BDT as a donor material and $\mathrm{PC}_{61} \mathrm{BM}$ as an acceptor material. The active layer composed of 1-BDT and $\mathrm{PC}_{61} \mathrm{BM}$ (denoted as 1-BDT:PC ${ }_{61} \mathrm{BM}$ ) was prepared by spin-coating a chloroform solution of $1: 1$ $(w: w)$ blends of the donor and acceptor materials onto the ITO/PEDOT:PSS substrates under a $\mathrm{N}_{2}$ atmosphere followed by vapour depositing $\mathrm{Ca} / \mathrm{Al}$ as an anode. ${ }^{9}$ In our previous studies, ${ }^{6}$ we reported $\mathrm{BHJ}$ solar cells of $\mathbf{1}: \mathrm{PC}_{61} \mathrm{BM}$, whose active layers were prepared by using a solvent mixture of chloroform and toluene $(1: 1 \mathrm{v} / \mathrm{v})$. For these devices, we observed the highest PCE of $2.1 \%$ after thermal annealing. However, the addition of toluene, even in $10 \%$ to chloroform, as a co-solvent for the preparation of
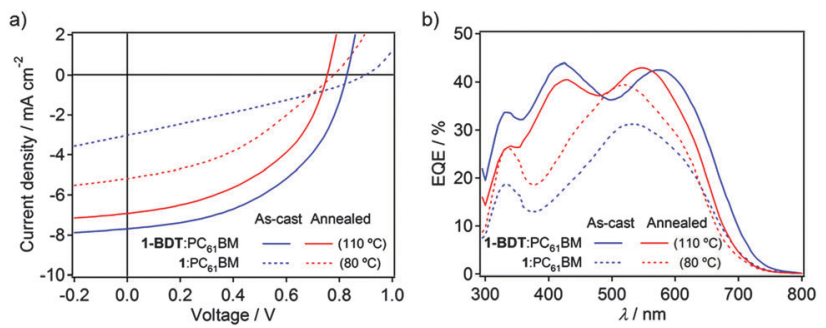

Fig. 4 (a) Current-voltage $(\mathrm{J}-\mathrm{V}$ ) characteristics of $\mathrm{BHJ}$ solar cells using $1: 1$ (w: w) blend films of 1-BDT and $\mathrm{PC}_{61} \mathrm{BM}$ (solid lines) and 1 and $\mathrm{PC}_{61} \mathrm{BM}$ (dotted lines) before (blue) and after annealing (red). (b) EQE spectra of the devices of 1-BDT:PC ${ }_{61} B M$ (solid lines) and 1:PC ${ }_{61} B M$ (dotted lines) before (blue) and after annealing (red). Film thickness: 100-120 nm.
1-BDT:PC ${ }_{61} \mathrm{BM}$ seriously decreased the solubility of 1-BDT. In the present study, we thus fabricated solar cells of $1: \mathrm{PC}_{61} \mathrm{BM}$ under the same condition as 1-BDT: $\mathrm{PC}_{61} \mathrm{BM}$ in order to focus on the introduction of the BDT unit.

In Fig. 4a and Table 2, the device properties of solar cells using as-cast and thermally annealed films of 1-BDT: $\mathrm{PC}_{61} \mathrm{BM}$ and 1:PC ${ }_{61} \mathrm{BM}$ are compared. The as-cast device of 1-BDT: $\mathrm{PC}_{61} \mathrm{BM}$ showed significant improvements in $J_{\mathrm{sc}}$ and $\mathrm{FF}$ compared to that of $1: \mathrm{PC}_{61} \mathrm{BM}$, leading to a PCE of $2.98 \%$, far greater than that of $1: \mathrm{PC}_{61} \mathrm{BM}(0.76 \%)$. The improved $J_{\mathrm{sc}}$ is rationalized by a higher charge carrier mobility of 1-BDT $\left(1.2 \times 10^{-5} \mathrm{~cm}^{2} \mathrm{~V}^{-1} \mathrm{~s}^{-1}\right)$ than that of $\mathbf{1}\left(\sim 10^{-7} \mathrm{~cm}^{2} \mathrm{~V}^{-1} \mathrm{~s}^{-1}\right)$, as estimated by the topcontact bottom-gate configuration organic field effect transistor (OFET) fabricated using solution-processed thin films (Fig. S7, $\mathrm{ESI} \dagger$ ). The external quantum efficiency (EQE) spectrum of the 1-BDT: $\mathrm{PC}_{61} \mathrm{BM}$ device exhibited a panchromatic spectral response over the entire excitation spectral range, indicating the contribution of both 1-BDT and $\mathrm{PC}_{61} \mathrm{BM}$ on the photocurrent generation. The maximum EQE value of $42 \%$ was observed at $420 \mathrm{~nm}$ and $580 \mathrm{~nm}$, which corresponds to the absorption maxima of the BDT unit and the oligothiophene backbone, respectively (Fig. 4b and Fig. S8, ESI $\dagger$ ). The increased EQE response in the shorter wavelength region reflects the positive influence of the BDT unit both on light harvesting and on the charge carrier mobility. Unlike 1: $\mathrm{PC}_{61} \mathrm{BM}$, the device performance was reduced upon annealing the film of 1-BDT:PC ${ }_{61} \mathrm{BM}^{10}$

The surface morphology of 1-BDT: $\mathrm{PC}_{61} \mathrm{BM}$ was studied by AFM (Fig. S9, ESI $\dagger$ ). Although no well-defined nanostructure was imaged for the as-cast film, the thermally annealed films exhibited rod-like nanostructures. The rod-like morphology became well-defined with the increasing annealing temperature. The similar effect of thermal annealing on the nanostructure change was observed for $1: \mathrm{PC}_{61} \mathrm{BM}$, wherein the growth of nanorods improved the solar cell performance. The reason why the solar cell performance of 1-BDT: $\mathrm{PC}_{61} \mathrm{BM}$ was decreased by thermal annealing albeit the growth of rod-like nanostructures is unclear at the present, presumably a phase-separated structure optimum for this semiconducting material was already achieved through solution processing. ${ }^{11}$

In addition to the surface morphology, the packing structure of the 1-BDT: $\mathrm{PC}_{61} \mathrm{BM}$ film was investigated by powder X-ray diffraction (PXRD) in addition to that of 1-BDT in the neat film. A thin film of 1-BDT, prepared by the evaporation of $\mathrm{CHCl}_{3}$ solution $\left(c=3.8 \times 10^{-3} \mathrm{M}, 5 \mathrm{mg} \mathrm{mL} \mathrm{mL}^{-1}\right)$, displayed two broad

Table 2 Photovoltaic properties of the $\mathrm{BHJ}$ solar cells based on 1-BDT and 1 as the donor and $\mathrm{PC}_{61} \mathrm{BM}$ as the acceptor under the illumination of AM 1.5G, $100 \mathrm{~mW} \mathrm{~cm}^{-2}$

\begin{tabular}{|c|c|c|c|c|c|}
\hline BHJ films & Annealing temp. $\left({ }^{\circ} \mathrm{C}\right)$ & $V_{\mathrm{oc}}(\mathrm{V})$ & $J_{\mathrm{sc}}\left(\mathrm{mA} \mathrm{cm}^{-2}\right)$ & $\mathrm{FF}(\%)$ & PCE $(\%)$ \\
\hline & 50 & $0.79 \pm 0.05$ & $7.02 \pm 0.23$ & $47.7 \pm 0.9$ & $2.63 \pm 0.08$ \\
\hline & 80 & $0.73 \pm 0.05$ & $6.76 \pm 0.28$ & $48.7 \pm 1.0$ & $2.38 \pm 0.06$ \\
\hline \multirow[t]{2}{*}{$1: \mathrm{PC}_{61} \mathrm{BM}$} & as-cast & $0.88 \pm 0.03$ & $2.97 \pm 0.06$ & $28.9 \pm 0.6$ & $0.76 \pm 0.04$ \\
\hline & 50 & $0.80 \pm 0.09$ & $2.53 \pm 0.04$ & $28.4 \pm 1.1$ & $0.58 \pm 0.09$ \\
\hline
\end{tabular}



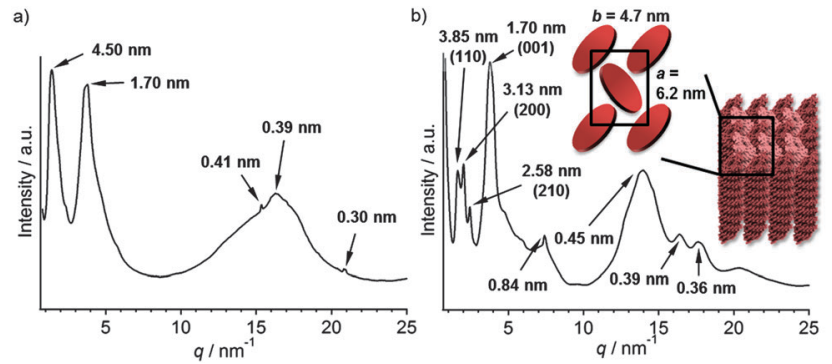

Fig. 5 PXRD patterns of bulk samples of (a) 1-BDT and (b) 1-BDT:PC ${ }_{61} B M$ at $25{ }^{\circ} \mathrm{C}$ in a glass capillary (diameter: $1.0 \mathrm{~mm}$ ). Values in parentheses denote Miller indices.

diffraction peaks in the lower angle region, corresponding to $d=4.5 \mathrm{~nm}$ and $1.7 \mathrm{~nm}$ (Fig. 5a). The $d$-value of $4.5 \mathrm{~nm}$ is close to the width of the rosette column (5.3 nm) observed by AFM, and the $d$-value of $1.7 \mathrm{~nm}$ can be attributed to the periodic length along the stacking direction of rosettes. The absence of other diffractions in the small angle region suggests that the 1-BDT rosette is organized in a columnar architecture without $2 \mathrm{D}$ ordering. In contrast, the thin film of 1-BDT: $\mathrm{PC}_{61} \mathrm{BM}$ showed explicit diffraction peaks with $d$-spacings which can be assigned to the diffractions from the (110), (200), (210), and (001) planes of a rectangular 2D lattice (space group: $P 2_{1} / a$, lattice parameters: $a=6.2 \mathrm{~nm}, b=4.7 \mathrm{~nm}$ ) in the $a b$ plane, which is complemented by the formation of one-dimensional columns along the $c$ axis, formed by the stacking of rosettes with a periodic length of $1.7 \mathrm{~nm}$ (Fig. 5b). ${ }^{12}$ These results show that 1-BDT can organize into a onedimensional columnar architecture via the formation of rosettes in the presence of $\mathrm{PC}_{61} \mathrm{BM}^{13}$

In summary, we have shown that the functionalization of the rosette-forming hydrogen-bonding oligothiophene with semiconducting $\pi$-units does not affect the formation of rosettes followed by the hierarchical organization into columnar structures. Further modification and functionalization of our supramolecular material design may provide unprecedented low-molecular-weight materials exhibiting outstanding optoelectronic properties as well as processability in addition to the unique self-organization motif.

The PXRD and STM studies of this work were supported by a Grant-in-Aid for Scientific Research on Innovative Areas " $\pi$-System Figuration: Control of Electron and Structural Dynamism for Innovative Functions" from the Ministry of Education, Culture, Sports, Science and Technology, Japan. Synchrotron XRD experiments were carried out at the BL45XU beamline of SPring-8, with the approval of the RIKEN SPring-8 Center (Proposal No. 20140056 and 20150068).

\section{Notes and references}

1 (a) S. Loser, C. J. Bruns, H. Miyauchi, R. P. Ortiz, A. Facchetti, S. I. Stupp and T. J. Marks, J. Am. Chem. Soc., 2011, 133, 8142-8145; (b) H. Shang, H. Fan, Y. Liu, W. Hu, Y. Li and X. Zhan, Adv. Mater., 2011, 23, 1554-1557; (c) Y. Sun, G. C. Welch, W. L. Leong,
C. J. Takacs, G. C. Bazan and A. J. Heeger, Nat. Mater., 2012, 11, 44-48; (d) T. Bura, N. Leclerc, S. Fall, P. Lévêque, T. Heiser, P. Retailleau, S. Rihn, A. Mirloup and R. Ziessel, J. Am. Chem. Soc., 2012, 134, 17404-17407; (e) K. Sun, Z. Xiao, S. Lu, W. Zajaczkowski, W. Pisula, E. Hanssen, J. M. White, R. M. Williamson, J. Subbiah, J. Ouyang, A. B. Holmes, W. W. H. Wong and D. J. Jones, Nat. Commun., 2015, 6, 6013-6021.

2 (a) H. Yamada, T. Okujima and N. Ono, Chem. Commun., 2008, 2957-2974; (b) Y.-J. Cheng, S.-H. Yang and C.-S. Hsu, Chem. Rev., 2009, 109, 5868-5923; (c) A. W. Hains, Z. Liang, M. A. Woodhouse and B. A. Gregg, Chem. Rev., 2010, 110, 6689-6735; (d) J. L. Delgado, P. A. Bouit, S. Filippone, M. A. Herranz and N. Martín, Chem. Commun., 2010, 46, 4853-4865; (e) A. Mishra and P. Bäuerle, Angew. Chem., Int. Ed., 2012, 51, 2020-2067; $(f)$ A. J. Heeger, Adv. Mater., 2014, 26, 10-27.

3 (a) H. Hoppe and N. S. Sariciftci, J. Mater. Chem., 2006, 16, 45-61; (b) F. Würthner and K. Meerholz, Chem. - Eur. J., 2010, 16, 9366-9373; (c) B. Walker, C. Kim and T.-Q. Nguyen, Chem. Mater., 2011, 23, 470-482; (d) P. M. Beaujuge and J. M. J. Fréchet, J. Am. Chem. Soc., 2011, 133, 20009-20029; (e) M. T. Dang, L. Hirsch, G. Wantz and J. D. Wuest, Chem. Rev., 2013, 113, 3734-3765; $(f)$ Y. Huang, E. J. Kramer, A. J. Heeger and G. C. Bazan, Chem. Rev., 2014, 114, 7006-7043.

4 (a) F. J. M. Hoeben, P. Jonkheijm, E. W. Meijer and A. P. H. J. Schenning, Chem. Rev., 2005, 105, 1491-1546; (b) A. C. Grimsdale and K. Müllen, Angew. Chem., Int. Ed., 2005, 44, 5592-5629; (c) S. S. Babu, V. K. Praveen and A. Ajayaghosh, Chem. Rev., 2014, 114, 1973-2129.

5 (a) A. El-ghayoury, A. P. H. J. Schenning, P. A. van Hal, J. K. J. van Duren, R. A. J. Janssen and E. W. Meijer, Angew. Chem., Int. Ed., 2001, 40, 3660-3663; (b) A. Wicklein, S. Ghosh, M. Sommer, F. Würthner and M. Thelakkat, ACS Nano, 2009, 3, 1107-1114; (c) R. B. K. Siram, K. Tandy, M. Horecha, P. Formanek, M. Stamm, S. Gevorgyan, F. C. Krebs, A. Kiriy, P. Meredith, P. L. Burn, E. B. Namdas and S. Patil, J. Phys. Chem. C, 2011, 115, 14369-14376. 6 S. Yagai, M. Suzuki, X. Lin, M. Gushiken, T. Noguchi, T. Karatsu, A. Kitamura, A. Saeki, S. Seki, Y. Kikkawa, Y. Tani and K. Nakayama, Chem. - Eur. J., 2014, 20, 16128-16137.

7 (a) Y. Liang, D. Feng, Y. Wu, S.-T. Tsai, G. Li, C. Ray and L. Yu, J. Am. Chem. Soc., 2009, 131, 7792-7799; (b) Y. Zou, A. Najari, P. Berrouard, S. Beaupré, B. R. Aïch, Y. Tao and M. Leclerc, J. Am. Chem. Soc., 2010, 132, 5330-5331; (c) J. Zhou, X. Wan, Y. Liu, Y. Zuo, Z. Li, G. He, G. Long, W. Ni, C. Li, X. Su and Y. Chen, J. Am. Chem. Soc., 2012, 134, 16345-16351; (d) Q. Zhang, B. Kan, F. Liu, G. Long, X. Wan, X. Chen, Y. Zuo, W. Ni, H. Zhang, M. Li, Z. Hu, F. Huang, Y. Cao, Z. Liang, M. Zhang, T. P. Russell and Y. Chen, Nat. Photonics, 2015, 9, 35-41.

8 Y. Kervella, E. Shilova, S. Latil, B. Jousselme and F. Silly, Langmuir, 2015, 31, 13420-13425.

9 After careful screening of various parameters for device fabrication, we have chosen chloroform as a processing solvent, $1: 1(\mathrm{w}: \mathrm{w})$ for the optimum D/A blend ratio and $100-120 \mathrm{~nm}$ for thicknesses of the active layer, which can be prepared with a total concentration of $10 \mathrm{mg} \mathrm{mL}^{-1}$ of the organic materials.

10 We also fabricated solar cells of 1-BDT and $\mathrm{PC}_{71} \mathrm{BM}$. However, the devices showed lower performance than those using $\mathrm{PC}_{61} \mathrm{BM}$. The highest PCE of the 1-BDT: $\mathrm{PC}_{71} \mathrm{BM}$ device is $=2.77 \%$. This might be due to the fact that both 1-BDT and $\mathrm{PC}_{71} \mathrm{BM}$ are highly aggregative, which induces a significant phase separation.

11 (a) A. Saeki, S. Yoshikawa, M. Tsuji, Y. Koizumi, M. Ide, C. Vijayakumar and S. Seki, J. Am. Chem. Soc., 2012, 134, 19035-19042; (b) T. Ghosh, A. Gopal, A. Saeki, S. Seki and V. C. Nair, Phys. Chem. Chem. Phys., 2015, 17, 10630-10639.

12 (a) S. Yagai, Y. Goto, T. Karatsu, A. Kitamura and Y. Kikkawa, Chem. - Eur. J., 2011, 17, 13657-13660; (b) S. Yagai, Y. Goto, X. Lin, T. Karatsu, A. Kitamura, D. Kuzuhara, H. Yamada, Y. Kikkawa, A. Saeki and S. Seki, Angew. Chem., Int. Ed., 2012, 51, 6643-6647.

13 (a) R. Pacios, D. D. C. Bradley, J. Nelson and C. J. Brabec, Synth. Met., 2003, 137, 1469-1470; (b) C. Melzer, E. J. Koop, V. D. Mihailetchi and P. W. M. Blom, Adv. Funct. Mater., 2004, 14, 865-870. 